\title{
Community Socio-Economic and Cultural Systems in the Utilization of Reef Fisheries: A Descriptive Study from the South Misool Marine Protected Area, Raja Ampat, West Papua
}

\author{
Selvi Tebaiy ${ }^{1}$, Marjan Batto ${ }^{2}$, Jemmy Manan ${ }^{3}$, Agnestesya Manuputty $^{4}$ \\ \{selvitebay1976@gmail.com $\left.{ }^{1}\right\}$ \\ Universitas Papua, Indonesia ${ }^{1,2,3,4}$
}

\begin{abstract}
This study aims to determine the socio-economic and cultural characteristics of the system of reef fisheries resource utilized by communities in the South Misool Marine Protected Area (KKPD) in Raja Ampat, West Papua, Indonesia. Research was conducted from January to March 2019 using descriptive methods. Data were collected through observation, structured interviews, and document review. Respondents (fish collectors) were interviewed at three village observation points: Wayaban (5 respondents), Namlol (15 respondents) and Yellu (6 respondents). Data were analyzed quantitatively to interpret and describe information collected in the field. The results showed that on average, the number of family members per household in all three observation points were 4-5 people (63.38\%), reef fishermen in South Misool have an average age range of 36-45 years (48\%) and most have elementary school education level $(50 \%)$. All fishermen in Wayaban village are from Kayoa village in Ternate (North Maluku) $(100 \%)$, half of fishermen $(50 \%)$ in Yellu village are from Yellu and the majority fishermen $(33 \%)$ in Namlol shelter are from Raja Ampat (Yellu and Fafanlap villages). The reef fish resources system in the area of the South Misool KKPD utilizes a customary conservation-based management system where Sasi practices are still implemented in conjunction with Western conservation approaches.
\end{abstract}

Keywords: Indigenous Conservation, Indigenous Sasi, Socio-Economic Cultural System, Reef Fisheries, South Misool KKPD, Raja Ampat.

\section{Introduction}

The establishment of marine protected areas (MPAs) is increasing in many parts of the world [1][2][3]. The primary objective of a MPA is to conserve nature [4][5] through the protection of species [6][7] and threatened environments [8][9], as well as supporting biodiversity.

MPAs are important for protecting the marine environment, but they may also have large socio-cultural impacts. There is very little known or recognized about the socio-cultural impacts of MPAs. A study conducted by Badalamenti et al [10] about ecological effects of protection on Mediterranean marine reserves as in the Mediterranean found that little data is available on the consequences of the socioeconomic aspects of marine conservation areas.

Coastal and small island communities' members are generally employed in the marine sector working within the commercial nearshore and offshore fisheries, fish farming, sand 
mining and sea transportation industries. Education levels within coastal and small island communities are still low and local residences have poor structural and sanitary conditions. With the welfare conditions of communities relatively low, the pressure on coastal resources to meet the needs of coastal communities is extremely high.

Most people in the coastal areas of Indonesia work as fishermen, an occupation passed down from generation to generation from their ancestors. The characteristics of fishing communities are formed based on the dynamic nature of the marine resources they fish. Often, fishermen must move around to get the maximum catch causing fishermen to take high business risks. High business risks because fishing communities to live in harsh natural environments which is always overwhelmed by the uncertainty of doing business. Fishermen and coastal communities are economically and socially disadvantaged in terms of access to education and health services, and culturally disadvantaged compared to other community groups. Coastal or fishing communities in various regions are generally marked by the presence of several characteristics, such as poverty, socio-cultural underdevelopment and low human resource capacity.

Communities on small islands develop their socio-cultural characteristics from a process of cultural evolution that occurs following a series of interactions between humans and the environment. Human interactions with the environment occur in the manner of institutionalized patterns which produce an adaptation system that contributes a broader social system called culture [11].

The socio-economic problems faced by coastal communities are based on their interactions with the fishery resource which is impacted by ecosystem conditions, fisheries management policies and ease of access to fisheries resources. In Indonesia, this has been institutionalized and implemented through the establishment of a Regional Waters Conservation Area (KKPD). The purpose of the KKPD is to realize the sustainable management of marine resources. However, it is important that the socio-economic and cultural life of fishermen and the people who inhabit the KKPD area are considered as a part of the sustainable management of marine resources. One example of a KKPD that makes this consideration is KKPD Raja Ampat located in West Papua province.

One marine protected area zone designated within the Raja Ampat KKPD is located in the South Misool District, this location has been the recipient of numerous awards for the management of conservation areas that have been piloted at the national government level. The Raja Ampat KKP was established as a National Water Conservation Area (KKPN) on 3 September 2009 through the Decree of the Minister of Maritime Affairs and Fisheries RI Number Kep. 64/Men/2009. This decree establishes the waters of the Raja Ampat Islands and the surrounding seas as an Aquatic Nature Reserve (SAP). In additional the area managed conservasion area (KKPD) has been established since 2007 by the Regent of Raja Ampat regency under the name of small islands park and other KKPD.

The fishermen of South Misool obtain their livelihoods from the sea, and thus the sea provides for their daily needs. The South Misool fishing community is characterized by a form of social relations that occur between the fishermen and other communities around a conservation area. The social interaction of fishermen and the organization of work carried out is part of social adaptation for fishermen's survival [12] Based on this background, this study analyzes the socio-economic and cultural characteristics of South Misool communities, as well as how these communities utilize coral fishery resources in the South Misool zone of KKPD Raja Ampat. 


\section{Research Method}

\subsection{Research Time and Location}

This research was carried out in the South Misool KKPD from January to March 2019. The study focused on recruiting respondents who are fishermen and fish in two marine reservoirs, namely the Wayaban and Namlol fishing camps. The respondents came from the villages of Yellu, Harapan Jaya and Fafanlap (Figure 1).

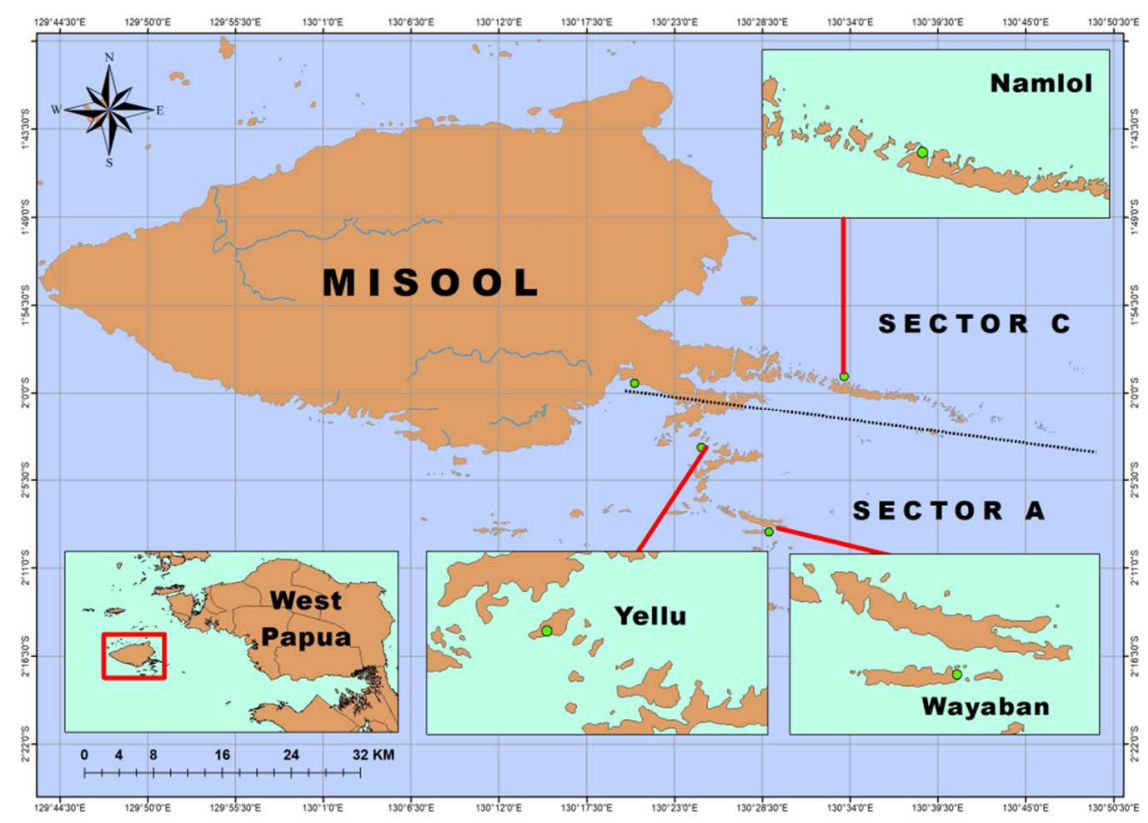

Fig. 1. Map of research location in Raja Ampat.

\subsection{Tools and Materials}

Tools and materials used in this study include tape recorders, cameras, writing instruments, and interview guidelines.

\subsection{Data Collection Technique}

Data was collected from primary and secondary data sources. Primary data was collected through observation and interviews. Interviews were conducted with several informants based on interview guidelines utilizing an open-ended response format. The total number of fishermen interviewed was 26: with 15 fishermen from Namlol, 6 fishermen from Yellu and 5 fishermen from Wayaban. Determination of the informants was done purposively with consideration to recruit respondents who (1) carry out fishing business activities (2) continuously settled in the villages of South Misool KKPD in the last 5 years, and, (3) know and understand matters relating to aspects of research including social, economic and cultural aspects. In order to understand the existing fisheries resource management system, 5 key respondents were interviewed including 1 owner of customary rights, 3 KKPD Raja Ampat 
staff from the South Misool zone and the Head of Fafanlap Village. Secondary data was collected through village monographs and annual reports, and scientific publications were obtained from the village office, Conservation International (CI) and the Raja Ampat Marine Protected Area Management Body (UPTD-BLUD Raja Ampat).

\subsection{Data Processing Techniques}

This research employs an exploratory descriptive methodology. Explorative descriptive research aims to describe the state of a phenomenon. This study is not intended to test certain hypotheses but only describe what variables, symptoms or states exist [13].

This study has obtained information about the socio-economic conditions of reef fishers at fish storage sites in the South Misool KKPD, namely Wayaban and Namlol, and to look closely at the conditions of local fishermen in Yellu Village. This information reveals existing fish resource and management models based on a customary conservation system. The presentation of data in the form of percentages, tables, and graphs provide an overview of the distribution of subjects according to variable value categories to help understand the state of data presented [14][15].

\section{Results and Discussion}

\subsection{Socio-economic and Cultural Characteristics of Fishermen in the South Misool KKPD}

Small island communities have their socio-cultural characteristics as a consequence of the process of cultural evolution that occurs from a series of processes of human interaction with the environment. Human interaction with their environment occurs in the manner of institutionalized patterns which produce an adaptation system that contributes a broader social system called culture [11].

The existence of KKPD as a regional space for the community has certain social functions, especially related to the open-access of natural resources to fulfill the living needs of a community group or a social system. These functions can be either direct or indirect economic functions that have become a tradition or habit for the community.

The direct functions can be in the form of natural resource utilization in the island ecosystem, while the indirect functions can be in the form of the use of islands as a shelter or temporary stopover for traditional fishers during bad weather or for certain ethnic groups or tribes that live on the sea [11].

\subsubsection{Social Aspects}

Some parameters that explain the characteristics of the social aspects are the distribution of the respondent's ethnicity, the number of family members in the respondent's household, the age distribution of the respondent and the education level of the respondent.

\subsubsection{Tribal Distribution}

The social system of a group of people is described by the ethnic distribution of the people who inhabit the area. Social communication, which is shown by the interaction between 
citizens, shows the culture of each community's tribe. Overall, members of an ethnic group claim cultural continuity across time, although historians and anthropologists have documented that many of the values, practices, and norms that are considered to show continuity with the past are relatively new findings. Ethnicity is characterized by recognition from others of the group's characteristics such as cultural similarity, language, religion, behavior, and biological characteristics.

The following figure illustrates the distribution of tribes in the area of the South Misool KKPD at three observation points. Figure 2 shows the distribution of tribes in Yellu Village consisting of persons from the Ternate, Yellu, Flores, and Flores tribes. As many as $50 \%$ of the people living in Yellu Village are those from the original South Misool tribe, while the Tidore and Flores tribes make up 17\% of respondents and 16\% are from the Ternate ethnic group. At the fish storage place in Wayaban, all fishermen or respondents $(100 \%)$ are from the Ternate tribe, primarily from Kayoa in South Halmahera District. These fishermen, in general, come from a long generational line of fishermen in their home villages and have been involved in fishing activities with parents and families.
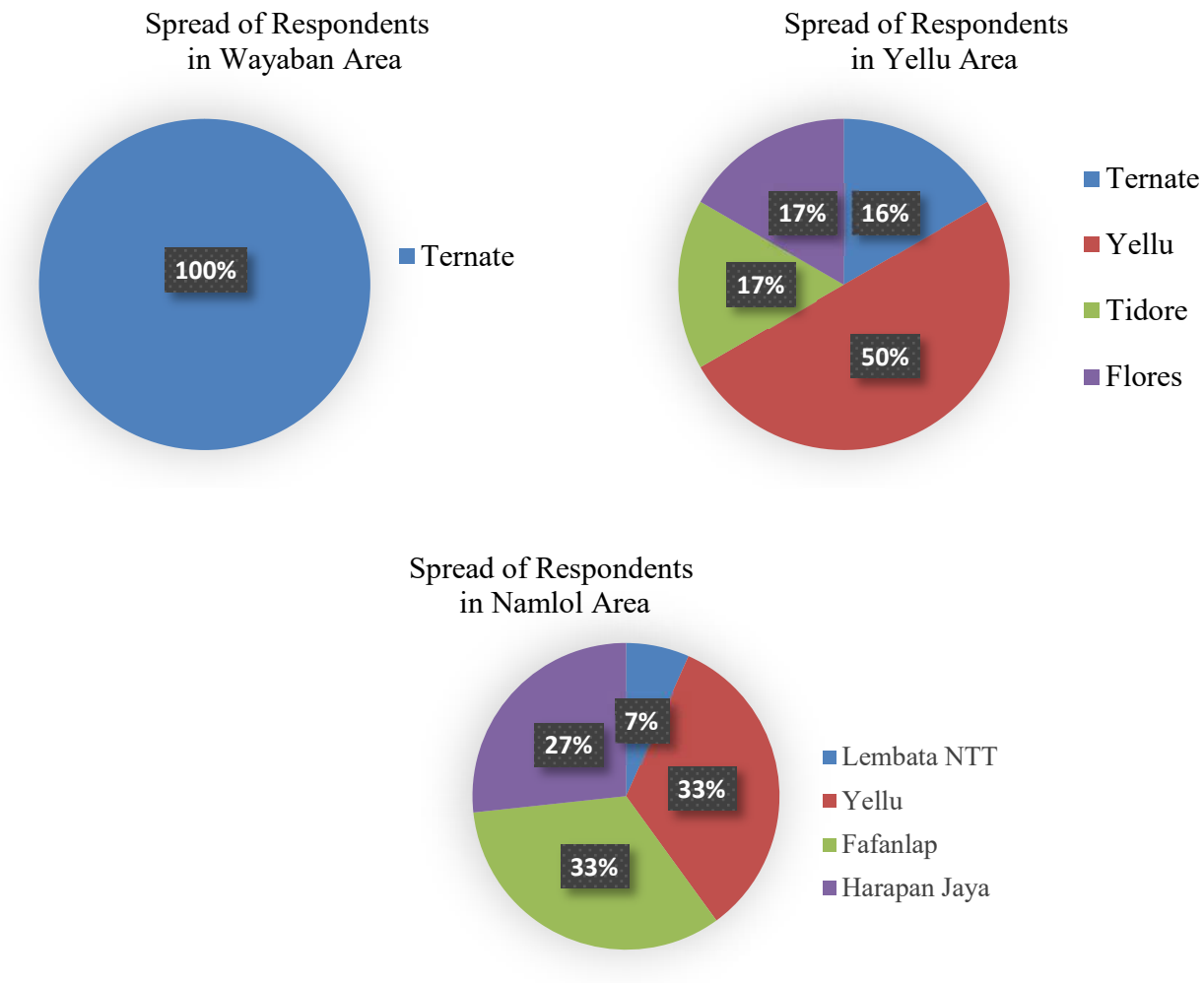

Fig. 2. Distribution of respondent's rate. 


\subsubsection{Number of Family Members}

Other variables that influence income are the number of family members. Previous studies $[16][17][18]$ use the variable number of family members as one of the factors affecting income. [16] Used cross-section data to examine income and poverty in three rural areas of Bali, Indonesia.

Family size is an important factor affecting household poverty rates $[19][20][21][22][23][16]$. This factor may affect poverty because as long as household income remains, increasing the number of families will reduce the level of real consumption of family members. Additionally, even though each household member has income, income per capita can decrease with the increasing number of families due to diminishing marginal productivity $[20][22][16]$.

The number of family members is very important in supporting efforts to increase family income. If family members are of productive age then social capital is present in a household. The highest number of family members in the distribution of respondents amounted to 6-7 people per household is $66 \%$, the number $<5$ people per household is $19 \%$ while the number of family members per household $>7$ people is $15 \%$. Figure 3 clarifies this result.

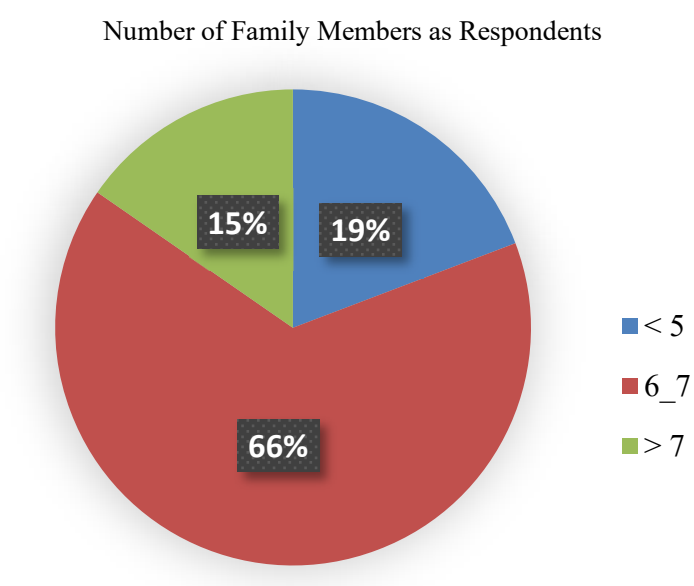

Fig. 3. Distribution of number of family members.

\subsubsection{Age of Respondents}

Previous research conducted by [24][25][26][18], show that age influences income. However, the effect of age on income is indeed not large (parameter coefficient values between 0.023 and 0.106 ). Young people generally do not have the responsibility of being a breadwinner for the family, they generally go to school, so they do not have a great impact on household income. The population in the $22-55$ years age group, especially men, are generally required to contribute to making a living for the household and therefore the household employment rate is relatively large. Furthermore, as individuals above the age of 55 years lose the ability to work and employment rates decline, and household employment rate is generally low. Figure 3 illustrates the age distribution of respondents. 


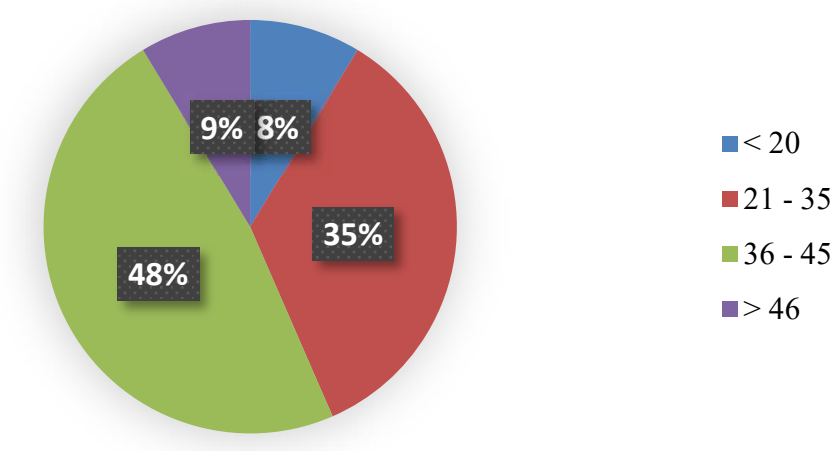

Fig. 4. Age distribution of respondents.

\subsubsection{Education Level}

Studies have found that the level of education influences income [24][25][26][18][17]. The coefficient values of the educational variable parameters are between 0.023 and 0.107 . The higher the level of education the more time available to work. The higher the education, the greater the tendency to work, and the greater the level of work participation [27].

Approximately $50 \%$ of respondents had received education at the elementary school level (SD), 38\% received education at the junior high school level and $12 \%$ did not attend school (Figure 5). The quality of the level of education respondents received seemed low. The cause of the low level of formal education in coastal communities is due to weak family economic conditions, limited costs in their neighborhood, limited accessibility and thinking patterns or views on the importance of education [28]. Education will influence the ability to absorb new information in developing fisheries technology innovation and adoption abilities.

Factors that inhibit innovation in the fishing community closely mirror the farming community, as fishermen display the individual characteristics of low-income farmers such as low education and fear of taking risks such as instant innovation. Characteristics of innovations that inhibit the innovations amongst fishermen and farmers are the level of complexity, relative superiority, economic value, level of ease of trying and political assistance [29].

Dsitribution of respondent education

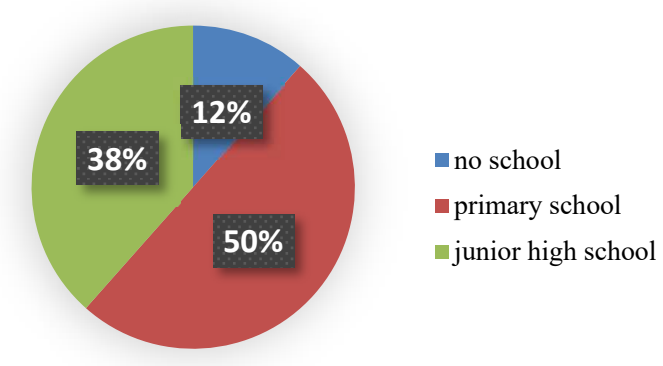

Fig. 5. Distribution of respondent education. 


\subsubsection{Economic Aspects}

Fishing by fishermen is an economically and extractive production process, that is, taking natural products without reversing some of the results for future use. Fishermen are groups of people whose lives depend directly on marine products, either through catch or cultivation. Fishermen generally live on the beach in a residential neighborhood close to the location of their economic activities. To conduct a fishing business, fishermen need money and bear both production and fixed costs.

\subsubsection{Production Costs}

Types of production costs incurred by fishermen in South Misool include the purchasing of supplies such as nylon, fishing rods, drinking water, cigarettes, fuel oil (ice), ice cubes, the cost of safekeeping goods transporting to the port, transportation costs of workers from storage to the port and costs for purchasing areca nuts (pinang). The distribution of production costs is generally used by fishermen in these two reservoirs (Figure 6).

Types of production costs one day fishing

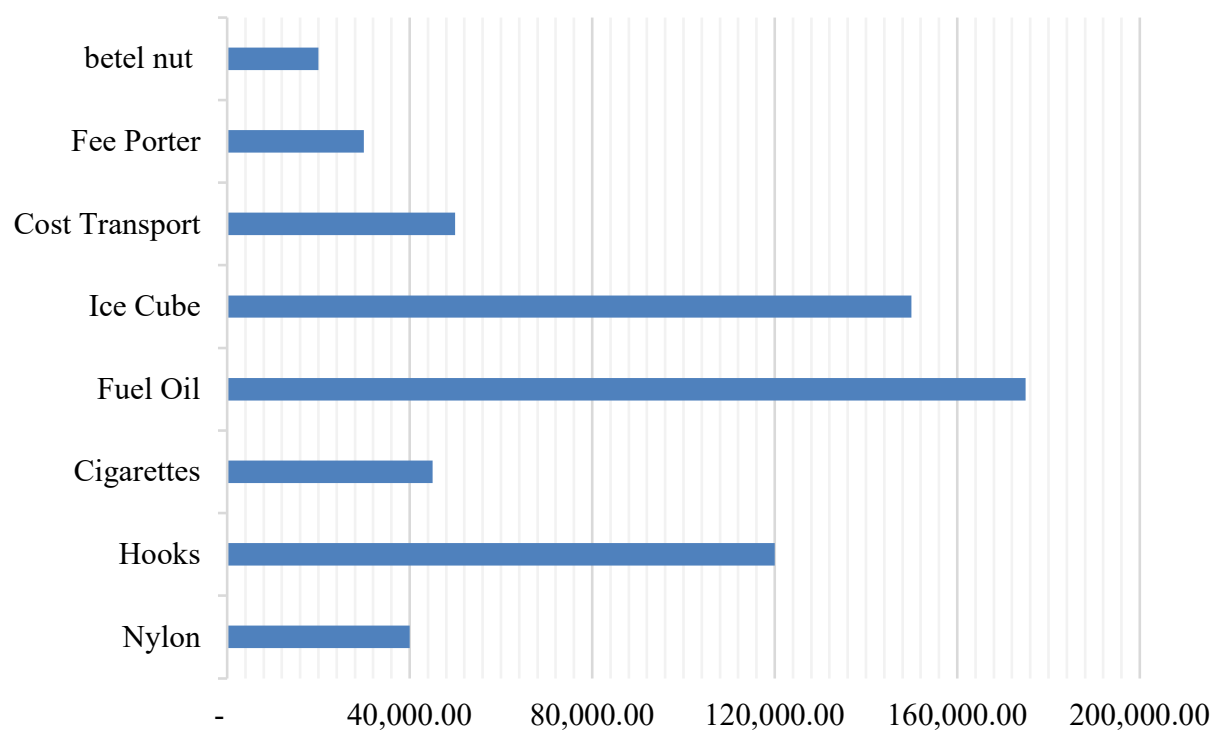

Fig. 6. Types of production costs in one trip to sea.

Economic efficiency is often only measured from the aspect of production, and less attention is given to non-production costs such as transaction costs. In a small-scale fishing operation, a lot of expenses outside of the production costs are borne by fishermen. This expenditure is not realized or has reduced the level of revenue from small-scale fishing businesses [30]. 


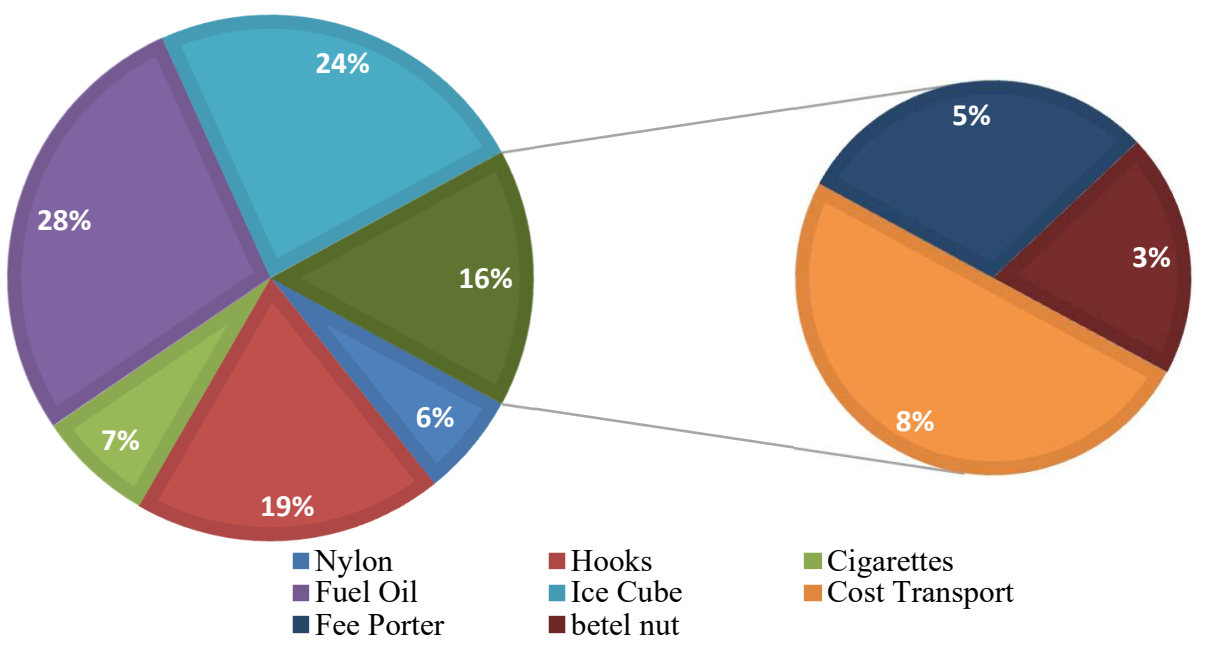

Fig.7. Percentage of production costs for one time at sea.

The percentage of production costs is adjusted to the needs and business orientation of each fisherman. The results showed that fuel was $28 \%$, ice cubes $24 \%$, hooks $19 \%$, while transport to port $16 \%$, cigarettes $8 \%$, labor costs from home to port $5 \%$ and areca nut only $3 \%$. The mechanism for providing production costs is carried out through a leasing system between fishermen and financiers.

\subsubsection{Types of fixed Costs and Production Rate}

Fixed costs are costs that remain constant at various levels of output produced by a fisherman. These costs are not affected by momentary fluctuations in the level of organizational activity. Although these costs are fixed and constant, it does not mean that these costs will not change in the future. These costs tend not to be changed in the short term. Fixed costs used by fishermen in the village of Yellu, collectors of Wayaban and Namlol are for items including the body of the boat and engine painting about $15 \mathrm{PK}$. This fixed cost or investment is provided by the investor or the fisherman. If the cost is met by the financier, the leasing mechanism as a form of initial capital is given to the fisherman.

\subsubsection{Type of Production and Work Time Outflow}

Production is a process of changing inputs into outputs so that the value of the goods increases. Input can consist of goods or services used in the production process, and output is goods or services produced from a production process [31]. Production can also be interpreted as the process of utilizing or utilizing all available sources by involving production factors (inputs) that are expected to realize outputs (outputs) and are of guaranteed quality, as well as well managed to meet human needs. 
The types of catch produced by respondents in South Misool include both live and dead fish. The type of live fish targeted is grouper that meets the export standard of $>1.1$ kilos. Grouper fish below the size of export standard is included in the group of dead fish that is sold together with non-target fish including gutila, singaro, bubara, mackerel, rockfish, redfish, and red telo fish. At the three study sites, there were differences in the average production volume, as well as different seaweed or trip times. (Table 1).

Table 1. Types of production and time spent

\begin{tabular}{ccccccc}
\hline \multirow{2}{*}{$\begin{array}{c}\text { Production } \\
\text { type }\end{array}$} & $\begin{array}{c}\text { Production } \\
\text { volume } \\
\text { /month }\end{array}$ & $\begin{array}{c}\text { Fishing } \\
\text { time } / \text { trip }\end{array}$ & $\begin{array}{c}\text { Production } \\
\text { volume } \\
\text { /month }\end{array}$ & $\begin{array}{c}\text { Fishing } \\
\text { time } / \text { trip }\end{array}$ & $\begin{array}{c}\text { Production } \\
\text { volume } \\
\text { /month }\end{array}$ & $\begin{array}{c}\text { Fishing } \\
\text { time } / \text { trip }\end{array}$ \\
\hline Live fishes & $80-96$ ind & $6-7$ hours & $76-80$ ind & $6 .-8$ hours & $32-48$ ind & $4-5$ hours \\
\hline Dead fishes & $6-8$ boks & $6-7$ hours & $16-20$ box & $6-8$ hours & $2-6$ box & $4-5$ hours \\
\hline
\end{tabular}

This difference is caused by the distance from the shelter to a different fishing ground. Mileage affects the amount of work time spent by each fisherman. Fishermen in Yellu make dead fish the catch target visible by spending 4-5 hours a day at sea. Fishermen in Namlol spend 6-8 hours on average at sea, while fishermen in Wayaban spend 6-7 hours at sea.

\subsubsection{Income of Fishermen}

Large-income families relative to the cost of living tend to reduce the number of family members that need to work, so the work participation rate is relatively low. Conversely, families whose living costs are very large relative to their income tend to increase the number of working family members, so the work participation rate is relatively high [32]. The income of respondents in Namlol, Yellu and Wayaban explained there are two types of production sources, namely the results of income from live fish and dead fish. Furthermore, respondents in Wayaban have a higher distribution of live fish income than Namlol and Yellu (Figure 8).

Average Distribution of Live Fish Income per month

$5,000,000.00$
$4,500,000.00$
$4,000,000.00$
$3,500,000.00$
$3,000,000.00$
$2,500,000.00$
$2,000,000.00$
$1,500,000.00$
$1,000,000.00$
$500,000.00$

$$
\begin{array}{r}
5,000,000.00 \\
4,500,000.00 \\
4,000,000.00 \\
3,500,000.00 \\
3,000,000.00 \\
2,500,000.00 \\
2,000,000.00 \\
1,500,000.00 \\
1,000,000.00 \\
500,000.00 \\
-
\end{array}
$$

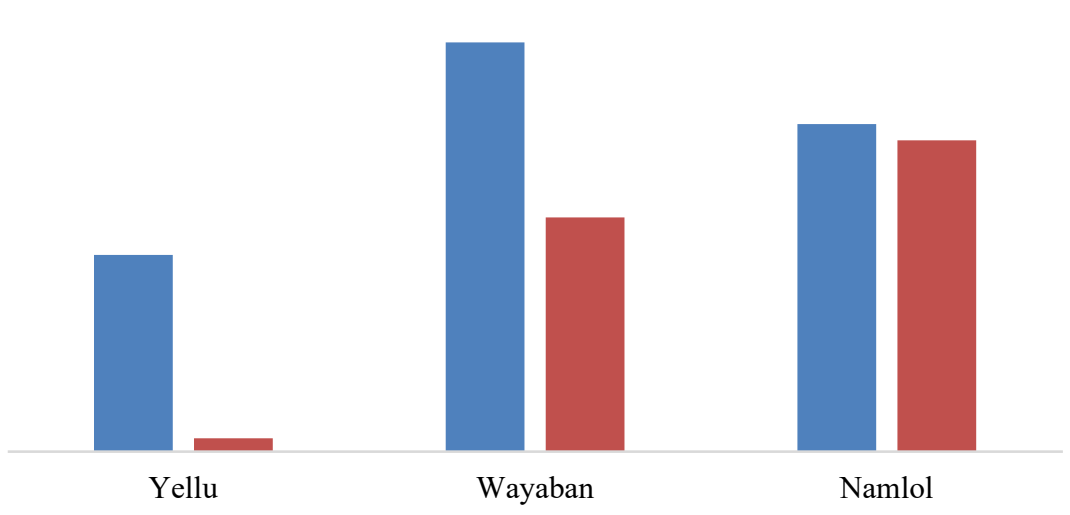

Fig. 8. Average distribution of live fish income. 
The average income distribution of live fish per month in Wayaban is between IDR. 2.500.000 to IDR 4.375.000. In Namlol the average income of respondents was reported to be between IDR 3.325.000 to IDR 3.500.000 and the average income for respondents in Yellu village was much lower at income reported between IDR 140.000 to IDR 2.100.000. The average income of dead fish from the interview results obtained by fishermen in Namlol has a higher income than the other two regions, between IDR 1.600.000 to IDR 2.000.000 (Figure 9).

\section{Average Distribution Of Dead Fish Income}

$2,500,000.00$

$2,000,000.00$

$1,500,000.00$

$1,000,000.00$

$500,000.00$

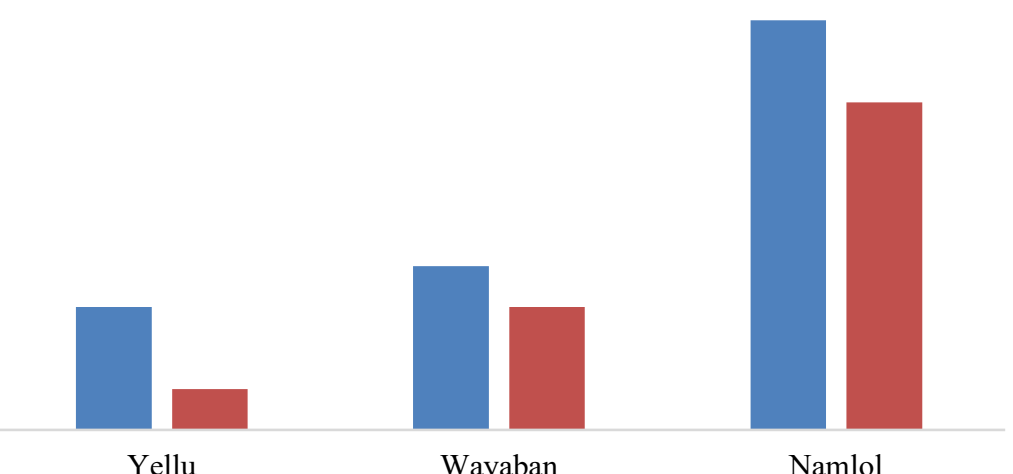

Fig. 9. Average distribution of dead fish income.

\subsection{Customary conservation-based management model of reef fisheries in the South Misool KKPD}

The socio-economic characteristics of reef fish fisheries in the South Misool KKPD include ethnic distribution, number of family members, average respondent age, average education level and economic variables such as fixed costs, production costs, types of production, and income distribution. Fishermen in Wayaban, Namlol and Yellu villages show that the patterns of utilization and production results are different among each fisherman in the three places. This is due to differences in ethnicity, values and different cultural backgrounds in assessing reef fish fishery resources and their utilization practices.

Using a cultural approach to reef fish fishing can be a model for the management of reef fish resources in the South Misool KKPD. One form of human interaction with and reaction to the natural environment is through the customary practice of sasi. The word sasi comes from the Maluku region meaning "prohibition". Indigenous sasi is rooted in Maluku culture and has been passed down by generations and generations of fishermen. Sasi is a prohibition order given by an authority to forbid the harvesting of agricultural and marine products before the specified time. This prohibition order is collective against an object or area and is based on the interests and needs of many people.

The tradition of sasi is an unwritten customary law of Indigenous peoples in Raja Ampat which prohibits the harvest of marine animals within a certain time period. In Western science, this can be translated to fishery closures in order to conserve a species. Depending on the species, the harvesting prohibition can last up to 24 months. After that, community 
members are allowed to catch fish simultaneously. Activities that are similar to the harvest period of fish and other sea products are also limited by a certain time, usually not more than 1 month.

By applying the sasi tradition, people can enjoy far more sea catches. The tradition gives marine biota time to reproduce well so that its sustainability is maintained. To support this local wisdom, the community has now implemented a surveillance patrol system in the customary territorial waters where the sasi tradition is carried out. Monitoring centers were also built at Gamfi Island (East Misool district), Waaf Island (West Misool district) and Jaam Island (South East Misool district).

The application of sasi adat (seasonal/ancestral sasi) has shifted, and now the determination of when sasi will occur is based on wind direction calculations during the southern and western wind seasons. The south season is the wave season in which 6 months of sea season is closed. In the shady season, or the western season (6 months), the community is able to looking for fish and another biota. Sasi adat requires that sasi lasts for 6 months, or seasonal sasi. The results of interviews with local people indicate that over the last 10 years the practice of traditional sasi is still being carried out. Sasi based on adat is carried out in several areas within the South Misool KKPD.

\section{Conclusion}

The socio-economic aspects of reef fish fisheries in the South Misool KKPD based on the interaction of fishermen with their environment are characterized by ethnic distribution, number of family members per household, average respondent age, averageeducation level and economic variables such as fixed costs, production costs, types of production, and income distribution from fishermen. The socio-economic differences between fishermen in the three observation areas were found across= ethnicity, education level, number of dependents in the family, business orientation, and cultural values shared by a community. Sasi is a cultural approach to reef fishing that can be used a model for the management of reef fish resources in the South Misool KKPD.

\subsection{Acknowledgment}

Thank you to ANBICORE Shera USAID for the support of this research funding.

\section{References}

[1] J. A. Dixon, L. Fallon Scura, and T. van't Hof, "Meeting ecological and economic goals: marine parks in the Caribbean," Ambio (Sweden), 1993.

[2] W. J. Ballantine, "Networks of" no-take' marine reserves are practical and necessary," Mar. Prot. areas Sustain. Fish. Sci. Manag. Prot. Areas Assoc. Wolfville, Nov. Scotia, Canada, pp. 13-20, 1995.

[3] T. S. Agardy, Marine protected areas and ocean conservation. Academic Press, 1997.

[4] S. Riggio, "Parchi marini del Mediterraneo. Aspetti naturalistici e gestionali," Atti del 1 Convegno Internazionale San Teodoro, pp. 171-181, 1989.

[5] M. T. Agardy, "Advances in marine conservation: the role of marine protected areas," Trends Ecol. Evol., vol. 9, no. 7, pp. 267-270, 1994.

[6] A. Panou, J. Jacobs, and D. Panos, "The endangered Mediterranean monk seal Monachus 
monachus in the Ionian Sea, Greece," Biol. Conserv., vol. 64, no. 2, pp. 129-140, 1993.

[7] A. W. Stoner and M. Ray, "Queen conch, Strombus gigas, in fished and unfished locations of the Bahamas: effects of a marine fishery reserve on adults, juveniles, and larval production," Fish. Bull., vol. 94, no. 3, pp. 551-556, 1996.

[8] A. García-Rubies and M. Zabala i Limousin, "Effects of total fishing prohibition on the rocky fish assemblages of Medes Islands marine reserve (NW Mediterranean)," Sci. Mar. 1990, vol. 54, num. 4, p. 317-328, 1990

[9] C. F. Boudouresque and M. A. Ribera, "Les espèces et les espaces protégés marins en Méditerranée, situation actuelle, problèmes et priorités," Les Zo. Protegées en Méditerranée, pp. 94-141, 1993.

[10] J. Badalamenti, F.; Mas, J.; D’Anna, G.; Pipitone, C.; Ruis, "Ecological effects of protection on Mediterranean marine reserves. 1st ECOMARE meeting - MAST III. Activities affected by protection. Task I - Theme 1. Palma de Mallorca, May 12 - 17, 1998," Cent. Ocean. Balear. Inst. Español Oceanogr. Palma Mallorca, 1998.

[11] S. Tebay, "Kondisi Sosial Ekonomi Dan Budaya Masyarakat Pulau-Pulau Kecil Sebagai Suatu Realitas- Studi Kasus Kepulauan Raja Ampat," in Prosiding Seminar Nasional Pengembangan Pulau-Pulau Kecil, 2011, pp. 177-186.

[12] S. Harpin, Pranata Rici Tri; Arif, "Strategi Adaptasi Nelayan Terhadap Penetapan Kawasan Konservasi Perairan Daerah Di Misool Selatan, KKPD Raja Ampa,” Jurnal. Kebijak. Sosek KP, vol. 5 , no. 2, 2015.

[13] S. Arikunto, "Metode Penelitian Suatu Pendekatan Praktek," Jakarta PT. Rineka Cipta, 2002.

[14] S. Azwar, Metode Penelitian. Yogyakarta: Pustaka Pelajar Offset, 2004.

[15] A. Chaer, Gramatika Bahasa Indonesia. Rineka Cipta, 1993.

[16] C. Firdausy and C. A. Tisdell, "Determinants of Rural Income and Poverty at the Village Level in Bali, Indonesia'," Malaysian J. Econ. Stud., vol. 29, no. 1, pp. 19-34, 1992.

[17] A. Yúnez-Naude and J. E. Taylor, "The determinants of nonfarm activities and incomes of rural households in Mexico, with emphasis on education," World Dev., vol. 29, no. 3, pp. 561-572, 2001.

[18] P. Lanjouw, "Nonfarm employment and poverty in rural El Salvador," World Dev., vol. 29, no. 3, pp. 529-547, 2001.

[19] D. Chernichovsky and O. Meesook, "Urban-rural food and nutrition consumption patterns in Indonesia," World Bank Staff Work. Pap., vol. 670, 1984.

[20] H. Sigit, "Income distribution and household characteristics," Bull. Indones. Econ. Stud., vol. 21, no. 3, pp. 51-68, 1985.

[21] M. Alamgir and S. Ahmed, "Poverty and income distribution in Bangladesh," Rural Poverty South Asia, pp. 11-38, 1988.

[22] S. Kuznets, Economic development, the family, and income distribution: Selected essays. Cambridge University Press, 2002.

[23] R. Gaiha, "Inequality, earnings and participation among the poor in rural India," J. Dev. Stud., vol. 23, no. 4, pp. 491-508, 1987.

[24] M. Swaminathan, "The determinants of earnings among low-income workers in Bombay: An analysis of panel data," J. Dev. Stud., vol. 33, no. 4, pp. 535-551, 1997.

[25] L. Martin-Hansen, "Defining inquiry," Sci. Teach., vol. 69, no. 2, p. 34, 2002.

[26] J. A. Berdegue and R. Fuentealba, "Latin America: The state of smallholders in agriculture," in IFAD conference on new directions for smallholder agriculture, 2011, vol. 24, p. 25.

[27] P. Simanjuntak, "Pengantar Ilmu Ekonomi Sumber Daya Manusia," LPFE UI, 1985.

[28] S. Tebaiy, J. Leiwakabessy, and E. T. Wambrauw, "Kontribusi Pendapatan Kelompok Usaha Perempuan Pesisir dalam Pengolahan Hasil Perikanan di Manokwari," J. Sumberd. Akuatik Indopasifik, vol. 1, no. 2, 2017.

[29] A. Warnaen and H. Cangara, "Faktor-faktor yang menghambat inovasi pada komunitas petani dan nelayan dalam meningkatkan kesejahteraan masyarakat di Kabupaten Takalar," KAREBA J. Ilmu Komun., vol. 2, no. 3, pp. 241-250, 2016.

[30] A. D. Patria, L. Adrianto, T. Kusumastanto, M. M. Kamal, and R. Dahuri, "Biaya Transaksi 
Usaha Perikanan Skala Kecil di Kabupaten Cilacap,” J. Sos. Ekon. Kelaut. dan Perikan., vol. 9 , no. 2, pp. 247-254, 2014.

[31] S. Adiningsih, "Ekonomi Mikro, edisi pertama," Yogyakarta BPFE Yogyakarta, 1999.

[32] A. Harsoyo, "Pengaruh Fertilitas Terhadap Partisipasi Tenaga Kerja Perempuan." Universitas Gadjah Mada, 2016. 